\title{
Survey for secondary dapsone and rifampicin resistance in Cuba
}

\author{
A. B. GONZÁLEZ,* J. L. MAESTRE, * \\ OLENIA HERNÁNDEZ,* YOLANDA COLUMBIÉ, $\dagger$ \\ N. ATRIO, $\ddagger$ MARITZA MARTIN, $\S$ \\ ANA M. FERNÁNDEZ \& J. RODRÍGUEZ* \\ *Instituto de Medicina Tropical 'Pedro Kouri', Apartado 601, Zona \\ Postal 13, Ciudad de la Habana, Cuba; †C.P.H.E.-Santiago de \\ Cuba, Cuba; †C.P.H.E.—Camagũey, Cuba; §C.P.H.E.—Villa \\ Clara, Cuba; and $\uparrow$ C.P.H.E.-Sancti Spiritus, Cuba
}

\section{Accepted for publication 14 December 1992}

\begin{abstract}
Summary A total of 1211 Cuban multibacillary leprosy patients treated for at least 5 years were clinically and bacteriologically examined. They were being treated according to a 2-phase monotherapy regimen with RMP first and DADDS afterwards. On skin-smear examination 50 patients were found positive, of which 9 showed a BI of $3+$ or higher at any site. With regard to the clinical status the only cases found with clinical signs of relapse were 5 out of 7 longstanding patients with BI of $4+$ and $5+$. A 6 th patient of this high BI group who showed a good clinical condition, except for a heavy infiltration of both earlobes, was receiving a second RMP course when examined and biopsied for this research. These 9 patients were biopsied and susceptibility tests to RMP and DDS performed. The results showed that in 1 case the Mycobacterium leprae were resistant to both drugs; the organisms from 2 other patients were susceptible to RMP but low-grade resistant to DDS. Those from another patient were susceptible to RMP and fully resistant to DDS. In 3 other cases the bacilli did not multiply in any of the mice but 1 of these strains was from the patient taking a second RMP course, therefore this strain might also be susceptible to RMP and resistant to DDS. In the last 2 cases multiplication was only observed in 2 of the controls and in 1 of the $0.0001 \%$ DDS treated mice; therefore, these experiments were not conclusive, and the AFB recovered were inoculated into fresh mice to repeat the tests but these failed to multiply.
\end{abstract}

\section{Introduction}

Multidrug therapy (MDT) has recently been implemented for the treatment of all Cuban leprosy patients. Between about 1962 and 1977, in Cuba chemotherapy of leprosy had consisted exclusively of dapsone (DDS) monotherapy, but in $1977^{1}$ this treatment 
strategy was drastically modified by the introduction of a 2-phase therapeutic regimen consisting of (a) treating all registered patients, whatever the duration of prior DDS treatment, with a course of $600 \mathrm{mg}$ daily rifampicin (RMP) monotherapy in skin-smear positive patients for 6 months and in skin-smear negative patients for 3 months, the RMP course being followed by acedapsone (DADDS), $225 \mathrm{mg}$ once a month, for an indefinite length of time in the case of the skin-smear positive patients and for 5 years in the case of the skin-smear negative patients, provided the lesions were cleared up and (b) giving the same therapeutic regimen to all patients detected thereafter. The drug intake for both RMP and DADDS was controlled by only having trained health personnel administer drugs to the patients throughout the country.

According to Lechat (M. Lechat, WHO/OPS Consultant. Report on a mission to Cuba. Nov. 8-15, 1984), when considering only the multibacillary types of the disease, the Cuban leprosy patients constitute a very heterogeneous group, which include:

1. Pre-1977 patients, who had been treated with DDS monotherapy for an indetermined time before 1977, and were still skin-smear positive at the initiation of RMP and harbouring DDS resistant bacilli. The post-RMP treatment with DADDS in these patients would have been ineffective. If RMP is not $100 \%$ effective in killing the DDS resistant bacilli, these patients would sooner or later present with a relapse. The time of onset of the relapse would, however, be delayed due to the reduction in bacillary load caused by RMP.

2. The same patients as (1) above but harbouring DDS sensitive bacilli. The post-RMP treatment with DADDS would have been effective to clean up the bacilli, provided the patient had not developed secondary resistance during the prolonged course of DADDS. 3. Pre-1977 patients who had been previously treated with DDS monotherapy for an indetermined time, and were skin-smear negative at the initiation of RMP, but possibly harbouring $M$. leprae 'persisters'. RMP followed by DADDS would have been effective to prevent relapse as long as treatment was maintained.

4. Post-1977 patients treated with RMP with no previous treatment with DDS. Some of them may have primary DDS resistance if infected before 1977. If infected after 1977 they may have primary DDS and/or RMP resistance.

A study was conducted to search for secondary DDS and RMP resistance, the results of which are reported herein.

\section{Materials and methods}

From April 1987 through May 1989, before MDT implementation, a total of 1211 leprosy patients residing in 7 Cuban provinces were seen. Of these, 992 were classified as lepromatous, 180 as dimorphous and 39 as indeterminate, according to the Madrid classification (Table 1). These indeterminate patients were found skin-smear positive when diagnosed. They all had begun treatment at least 5 years before and were receiving the prescribed DADDS therapy, apart from a patient who had intolerance to the drug. Their clinical records were abstracted, dermatological examination performed and skinsmears taken from both earlobes, both elbows and 1 or 2 other skin sites where active or residual lesions were observed.

Those patients with a Bacteriological Index (BI) of $3+$ or higher were biopsied, the 
Table 1. Distribution of patients according to sex and leprosy type

\begin{tabular}{lcccc}
\hline & \multicolumn{3}{c}{ Type } \\
\cline { 2 - 4 } Sex & Lepr. & Dimorph. & Indet. & Total \\
\hline Male & 662 & 85 & 20 & 727 \\
Female & 370 & 95 & 19 & 484 \\
Total & 992 & 180 & 39 & 1211 \\
\hline
\end{tabular}

Table 2. Distribution of patients diagnosed before 1977 according to the year of diagnosis

\begin{tabular}{lccc}
\hline Year & Number & $\begin{array}{c}\text { Skin-smear } \\
(1977)\end{array}$ & $\begin{array}{c}\text { Skin-smear }+ \\
\text { (study) }\end{array}$ \\
\hline Before 1936 & 6 & 1 & 0 \\
$1936-40$ & 8 & 1 & 0 \\
$1941-45$ & 29 & 3 & 1 \\
$1946-50$ & 53 & 10 & 0 \\
$1951-55$ & 44 & 10 & 3 \\
$1956-60$ & 66 & 13 & 5 \\
1961-65 & 149 & 34 & 2 \\
Sub-Total & 355 & 72 & 11 \\
1966-70 & 186 & 42 & 7 \\
Sub-Total & 541 & 114 & 18 \\
1971-76 & 233 & 84 & 3 \\
Total & 774 & 198 & 21 \\
\hline
\end{tabular}

specimens carried immediately in vacuum flasks immersed in wet ice to the laboratory in Havana where their bacilli were recovered and inoculated into the right hind footpad of groups of normal female BALB/C mice in a dose of $10^{4}$ organisms per footpad. The procedures employed for recovery of $M$. leprae from biopsy specimens, inoculation into footpads, harvests, smearing on to microscope slides, fixation and staining of smears and counting of acid fast bacilli (AFB) were the same as those described by Shepard, ${ }^{2,3}$ with minor modifications. For each specimen 50 mice were inoculated and then divided into 5 groups of 10 mice each; 1 group was left as control and given a normal diet, 3 other groups were fed DDS at a concentration of $0.01 \mathrm{~g}, 0.001 \mathrm{~g}$ and $0.0001 \mathrm{~g}$ per $100 \mathrm{~g}$ of powdered food, respectively, and the 5th group was administered RMP in a dosage of 10 $\mathrm{mg}$ per $\mathrm{kg}$ of body weight once a week by oesophageal cannula (gavage). Beginning 8 months after inoculation, 1 control mouse was killed at 2-3-month intervals (except for cases 15, 247 and 1211 which were all killed 14 months after inoculation) and their footpads harvested. When at least 1 of the controls reached the level of $5 \times 10^{5}$ AFB all mice were killed and counts were performed. The criterion for multiplication was the recovery of at least $10^{5}$ AFB per footpad harvested. 
Table 3. Distribution of patients diagnosed af ter 1976 according to the year of diagnosis

\begin{tabular}{cccc}
\hline Year & Number & $\begin{array}{c}\text { Skin-smear }+ \\
\text { (when diagnosed) }\end{array}$ & $\begin{array}{c}\text { Skin-smear }+ \\
\text { (study) }\end{array}$ \\
\hline 1977 & 46 & 28 & 0 \\
1978 & 49 & 34 & 2 \\
1979 & 56 & 37 & 1 \\
1980 & 59 & 43 & 3 \\
1981 & 73 & 53 & 5 \\
1982 & 64 & 42 & 4 \\
1983 & 68 & 52 & 9 \\
1984 & 22 & 14 & 5 \\
Total & 437 & 303 & 29 \\
\hline
\end{tabular}

\section{Results}

Table 2 shows that 774 patients were diagnosed (and began treatment) before 1977, and of these $198(25 \cdot 5 \%)$ were still skin-smear positive when the RMP treatment started in that year. The proportion of these latter patients diagnosed in the period 1966-70 (42/186$22.5 \%$ ), and therefore treated with DDS monotherapy for 7-11 years, was slightly, but not significantly, higher ( $p>0 \cdot 005$, Hypothesis test for 2 proportions) than that in those diagnosed before $1966(72 / 355-20 \cdot 2 \%)$ and significantly lower $(p<0 \cdot 001$, Hypothesis test for 2 proportions) than that in the group of 1971-76 (84/233-36.0\%), who had not been treated with the drug for more than 6 years. Of all pre-1977 patients, $21(2 \cdot 7 \%)$ were found skin-smear positive when examined for this investigation.

The number of patients detected between 1977 and 1984 (and therefore starting treatment with RMP) was 436, among whom $302(69 \cdot 2 \%)$ were found skin-smear positive at the time of diagnosis. When examined for this study $29(6 \cdot 6 \%)$ of these post-1977 patients were positive (Table 3 ). Thus 50 out of $1211(4 \cdot 1 \%)$ multibacillary patients treated for at least 5 years were found skin-smear positive. The BI values observed are shown in Table 4 . The majority showed a BI of only $1+$ or $2+$. Only 9 patients were observed with a BI equal to or above $3+$, and therefore eligible for mouse footpad inoculation. Of these latter, the 2 patients with a $\mathrm{BI}$ of $3+$ had received treatment for 5 and 6 years, respectively, while those 7 patients with BI of $4+$ and $5+$ were all diagnosed and started treatment before 1969.

With regard to the clinical status, the only cases found with clinical signs of relapse were 5 of the 7 long-standing patients with $\mathrm{BI}$ of $4+$ and $5+$. A 6 th patient in this high BI group who showed a good clinical condition, except for a heavy infiltration of both earlobes, was receiving a second RMP course, prescribed by his consultant dermatologist on account of his persistently high BI, when examined and biopsied for this research. The 7 th patient was carefully examined by the dermatologist co-ordinating the research team at the time of the biopsy, and, remarkably, no single clinical sign of relapse was observed.

The results of the susceptibility test to RMP and DDS of the M. leprae obtained from the 9 eligible patients are summarized in Table 5. In 3 instances (patients 15, 247 and 1211) no multiplication was observed in any mice, but patient 247 was taking a 2 nd course oí 
Table 4. Bacteriological Index values observed among 50 skin-smear positive patients

\begin{tabular}{lrcccc}
\hline & \multicolumn{5}{c}{ Bacteriological Index } \\
\cline { 2 - 6 } $\begin{array}{l}\text { Year of } \\
\text { diagnosis }\end{array}$ & 1 & 2 & 3 & 4 & 5 \\
\hline $1941-45$ & & & & 1 & \\
$1946-50$ & 1 & 1 & & & 1 \\
$1951-55$ & 2 & 1 & & 1 & 1 \\
$1956-60$ & 2 & & & & \\
$1961-65$ & 2 & 2 & & 3 & \\
$1966-70$ & 3 & & & & \\
$1971-75$ & 5 & 1 & 2 & & \\
$1976-80$ & 12 & 9 & 2 & & \\
$1981-84$ & 27 & 14 & 2 & 5 & 2 \\
Total & & & & & \\
\hline
\end{tabular}

Table 5. Results of the susceptibility tests to DDS and RMP of 9 patients with $\mathrm{BI}$ of $3+$ or higher

\begin{tabular}{|c|c|c|c|c|c|}
\hline \multirow[b]{2}{*}{ Patient } & \multirow[b]{2}{*}{ Control } & \multicolumn{3}{|c|}{$\mathrm{g}$ dapsone $/ 100 \mathrm{~g}$ of food } & \multirow{2}{*}{$\begin{array}{c}\text { RMP } \\
10 \mathrm{mg} / \mathrm{Kg}\end{array}$} \\
\hline & & 0.0001 & 0.001 & 0.01 & \\
\hline 15 & $0 / 9$ & $0 / 4$ & ND & ND & $0 / 4$ \\
\hline 247 & $0 / 9$ & $0 / 4$ & ND & ND & $0 / 4$ \\
\hline 447 & $6 / 6$ & $5 / 5$ & $6 / 9$ & $3 / 8$ & $7 / 8$ \\
\hline 656 & $9 / 9$ & $10 / 10$ & $9 / 9$ & $6 / 6$ & $0 / 8$ \\
\hline 684 & $3 / 4$ & $5 / 5$ & $0 / 8$ & ND & $0 / 7$ \\
\hline 736 & $8 / 8$ & $5 / 6$ & $0 / 9$ & ND & $0 / 8$ \\
\hline 905 & $0 / 6$ & $1 / 8$ & $0 / 8$ & $0 / 8$ & $0 / 8$ \\
\hline 967 & $2 / 6$ & $0 / 9$ & $0 / 8$ & $0 / 7$ & $0 / 6$ \\
\hline 1211 & $0 / 10$ & $0 / 4$ & ND & ND & $0 / 4$ \\
\hline
\end{tabular}

RMP at the time of the biopsy, therefore his strain might be susceptible to RMP and resistant to DDS since his BI was $5+11$ years after the commencement of the 2-phase therapy. The strain from patient 447 was found to be resistant to both RMP and all 3 different concentrations of DDS in the diet. In patient 656 the organisms were fully resistant to DDS but did not multiply in any of the RMP treated mice. In patients 684 and 736 only the controls and the mice treated with the lowest DDS concentration were positive, thus indicating a low-degree of DDS resistance. In the last 2 cases (patients 905 and 967) multiplication was only observed in 2 of the controls (Patient 967) and in 1 of the $0.0001 \%$ DDS treated mice (Patient 905), theref ore these experiments were not conclusive and the AFB recovered were inoculated into fresh mice to repeat the tests. Unfortunately, these strains failed to multiply; perhaps the number of viable organisms was too small when the final harvests were done 14 months after the first inoculation. 


\section{Discussion}

The number of patients examined for the present study represented about $30 \%$ of the total eligible population. In most instances fully documented data for treatment before 1977 were not available. However, DDS monotherapy was organized by the leprosy control programme established in 1962 and distributed free of charge to the patients. Since 1972, efforts began to be made to administer the drug under supervision and this was fully accomplished together with the introduction of the RMP-DADDS 2-phase regimen. Nevertheless, even before 1962 DDS was available to many patients when prescribed by private doctors or obtained at some public outpatient clinics for leprosy and venereal diseases scattered throughout the country or at the 2 leprosy hospitals then existing. Thus, the finding of a doubly resistant strain, 3 others showing resistance to DDS alone and another with inconclusive results for RMP but with DDS resistance, all from patients who received DDS monotherapy before the implementation of the RMP-DADDS 2-phase regimen, proves that drug resistance developed among the pre-1977 patients. The number of DDS resistant strains might have been greater, as is suggested by the observation that $114(21 \cdot 0 \%)$ of 541 patients treated for more than 6 years (diagnosed before 1971) still remained skin-smear positive in 1977 as compared to only $29(6.6 \%)$ among 437 post1977 patients, provided the 2-phase regimen did not speed up the clearance of dead bacilli and assuming that the proportion of those skin-smear positive among both pre- and post1977 patients was of the same order. Therefore, it seems likely that a greater DDS resistant reservoir had developed but had mostly been sterilized by the RMP action. This presumption is further supported by the observation that the majority of those pre-1977 patients found positive when examined for the present study showed scanty granular or fragmented organisms in the Ziehl-Neelsen stained smears.

As concerns RMP resistance, it is remarkable that only a single strain exhibiting this condition was found. Since the relapsed patient harbouring this RMP-DDS resistant strain was diagnosed in 1966 and received DDS monotherapy, it is conceivable that his M. leprae were already DDS resistant when he started the RMP treatment in 1977. Otherwise, the reduced number of DDS susceptible organisms persisting after the 6month RMP course would probably not have multiplied due to the subsequent DADDS therapy. Recently, Grosset et al. ${ }^{4}$ reported on $22 \mathrm{RMP}$ resistant $M$. leprae strains isolated from 39 multibacillary patients who relapsed among a group of 408 who were known to have been treated by some non-standard RMP regimen. It was also found that almost all of these RMP resistant strains were resistant to DDS as well. It is difficult to put forward an explanation for the striking difference concerning the frequency of RMP resistance noted between the strains from the Cuban patients and those reported by Grosset et al. ${ }^{4}$ However, the results of an earlier study on primary DDS resistance conducted by the author $^{5}$ from 1982 through 1985 could help. In that study, only 3 of 46 untreated lepromatous patients were found to harbour resistant strains, all 3 showing low-grade resistance. Moreover, both the proportion of $0.0001 \%$ DDS treated mice showing multiplication and the number of organisms recovered were much less than in the control mice. Had the present criterion for multiplication been used at that time, then the number of primary DDS resistant strains would have been 2 instead of 3. Since primary DDS resistance is regarded as an epidemiological indicator of acquired DDS resistance it may be that the latter was relatively late in occurrence in Cuba due to the effort to achieve regular unsupervised and supervised treatment made since 1962 and 1972, respectively. If 
this was so, then the DDS resistant $M$. leprae population in most patients in whom it emerged might not, by 1977, have reached the size required for the spontaneous emergence of RMP resistant mutants, which is thought to be not greater than 1 in $10^{9}$ to $10^{10}$ viable organisms. ${ }^{4}$

The failure to find RMP resistant strains among the post-1977 patients might also be explained from the results of the above-mentioned primary DDS resistance study. RMP resistant mutants could have multiplied to some extent during the 6-month RMP course but being presumably susceptible to DDS their multiplication would be arrested by the subsequent DADDS treatment.

The fact that 4 patients actually relapsed clinically and/or bacteriologically with RMP susceptible $M$. leprae, 3 of them with proved DDS resistance (Patients 656, 684 and 736) and a 4th (Patient 905) with proved DDS resistance, though with inconclusive results for RMP, points to the risk of relapse after effective treatment is stopped because of the activity of the so-called $M$. leprae 'persisters' and to the need for a long period of surveillance before a multibacillary patient is released from control. The present results serve to add to the amount of previously existing evidence and knowledge which gave rise to the currently accepted views in favour of MDT as a means of avoiding the emergence of drug resistance in multibacillary leprosy.

\section{Acknowledgement}

This investigation received financial support from the UNDP/WORLD BANK/WHO Special Programme for Research and Training in Tropical Diseases (TDR).

\section{References}

1 Abreu D. et al. Neuvo Programa de Control de Lepra. Ministerio de Salud Pública. Cuba. 1977.

2 Shepard CC. The experimental disease that follows the injection of human leprosy bacilli into footpads of mice. J Exp Med, 1960; 112: 445-54.

3 Shepard CC, McRae DH. A method for counting acid-fast bacteria. Int J Lepr, 1968; 36: 78-82.

${ }^{4}$ Grosset JH, Guelpa-Lauras CC, Bobin P, Brucker G, Cartel JL, Constant-Desportes M, Flageul B, Frederic M, Guillaume JC, Millan J. Study of 39 documented relapses of multibacillary leprosy af ter treatment with rifampicin. Int J Lepr, 1989; 3: 607-14.

5 González AB, Hernández O, Suárez O, González-Abreu E, Rodríguez JE. Survey for primary dapsone resistance in Cuba. Lepr Rev, 1986; 57: 341-6. 


\title{
Enquête sur la résistance secondaire à la dapsone et la rifampicine à Cuba
}

\author{
A. B. Gonzalez, J. L. Maestre, Olenia Hernandez, Yolanda Columbié, \\ N. Atrio, Maritza Martin, Ana M. Fernandez et J. Rodriguez
}

Résumé Un total de 1211 Cubains lépreux multibacillaires, traités pendant a u moins 5 ans, ont été examinés cliniquement et bactériologiquerent. Ils recevaient un traitement basé sur une monothérapie à deux phases, avec RMP en premier lieu, suivi de DADDS en un deuxième temps. A l'examen d'un frottis de peau, 50 patients ont été trouvés positifs, dont 9 présentaient un IB de $3+$ ou plus à tous les sites. Quant à l'état clinique, les seuls cas présentant des signes cliniques de rechute ont été 5 des 7 patients anciens avec des IB de $4+$ et $5+$. Un sixième patient de ce groupe à IB élevé, qui était en bonne condition clinique à part une forte infiltration des lobes des deux oreilles, recevait un second traitement de RMP lorsqu'il a été soumis à un examen et une biopsie pour ce projet de recherche. Des biopsies et des tests de sensibilité à RMP et à DDS ont été pratiqués chez ces 9 patients. Les résultats ont montré que dans un cas $M$. leprae était résistant aux deux drogues; les germes isolés de deux autres patients étaient sensibles à RMP mais faiblement résistants à DDS. Ceux d'un autre patient étaient sensibles à RMP et complètement résistants à DDS. Dans 3 autres cas les bacilles ne se sont multipliés dans aucune des souris, mais une de ces souches provencit du patient en cours de son second traitement par RMP, donc cette souche pourrait aussi être sensible à RMP et résistante à DDS. Dans lex deux derniers cas, on a observé la multiplication seulement chez deux des témoins et chez une des souris traitées au DDS à $0,0001 \%$; on ne pouvait donc pas conclure sur ces expériences; les AFB récupérés ont été inoculés à des souris neuves pour répéter les tests, mais ne se sont pas multipliés.

\section{Estudio sobre la resistencia secundaria a la Dapsona y la Rifampicina en Cuba}

\author{
A. B. González, J. L. Maestre, Olenia Hernández, Yolanda Columbié, \\ N. Atrio, Maritza Martin, Ana M. Fernandez y J. Rodríguez
}

Resumen Un total de 1211 pacientes leprosos multibacilares cubanos que habían sido tratados por un mínimo de 5 años, fueron examinados clínica y bacteriológicamente. Fueron tratados de acuerdo con un régimen monoterápico bifásico primero con RMP y luego con DADDS. 50 pacientes fueron positivos al examen por frótis, 9 con un BI de 3 + o más en cualquier sitio. Respecto al estado clínico, los únicos casos con indicaciones clínicas de recaída fueron 5 de 7 pacientes de mucho tiempo con BI de $4+$ y $5+$. Un sexto paciente de este grupo de alto BI en buen estado clínico excepto por una infiltración intensa de los lóbulos de las orejas, recibía una segunda serie de RMP cuando se le examinó e hizo una biopsia para este estudio. Se realizaron pruebas de biopsia y susceptibilidad a RMP y DDS en 9 pacientes. Los resultados indicaron que en 1 caso, Mycobacterium leprae resistía ambas drogas; los organismos de 2 otros pacientes erán sensibles a la RMP, pero tenían resistencia inferior a DDS. Los de otro paciente eran sensibles a RMP y totalmente resistentes a DDS. En 3 otros casos, los bacilos no se reprodujeron en cualquiera de los ratones, pero 1 de esta cepas era del paciente en la segunda serie de RMP y, por lo tanto, es posible que esta cepa sea sensible a RMP y resistente a DDS. En los últimos 2 casos, se observó reproducción solamente en 2 de los controles y en 1 de los ratones tratados con $0,0001 \%$ de DDS. Por lo tanto, estos experimentos no fueron conclusivos y se inocularon ratones nuevos con el AFB que se recuperó para repetir las pruebas, pero no se reprodujo. 